\title{
Empowerment of women through self-help group in Marathwada region
}

\author{
R.P. KADAM*, S.M. UMATE ${ }^{1}$, G.S. PAWAR ${ }^{1}$ AND R.G. NAIR \\ Department of Extension Education, Vasantrao Naik Marathwada Krishi Vidyapeeth, \\ PARBHANI (M.S.) INDIA
}

\begin{abstract}
The present study was conducted in Parbhani district with a view to know the information about empowerment of women through self help group. The present study was conducted in Parbhani district which was based on random selection in Marathwada region of Maharashtra state during the year 2013-2014. Three talukas were purposively selected from the Parbhani district and from that four villages were purposively selected on the basis of maximum number of self-help group. From each village ten women respondents were selected by lottery method, thus, total sample size will be 120 . The result revealed that 36.67 per cent women members of SHGs belonged to medium empowerment category. The percentage of women members of SHGs to high empowerment category were 18.33 per cent. About 15.83 per cent women members of SHGs belonged to low empowerment category while 15.00 per cent women members of SHGs belonged to very low empowerment category and 14.17 per cent women members of SHGs belonged to very high empowerment category. There was positive and significant relationship between empowerment and profile of women members of self-help group.
\end{abstract}

KeY Words : Women empowerment, Profile, Self-help group

View Point Article : Kadam, R.P., Umate, S.M., Pawar, G.S. and Nair, R.G. (2014). Empowerment of women through self-help group in Marathwada region. Internat. J. Home. Sci. Extn. \& Comm. Mgmt., 1 (2): 127-133.

Article History : Received : 19.05.2014; Revised : 10.06.2014; Accepted : 22.06 .2014 